Огляди літератури, оригінальні дослідження, погляд на проблему, випадок з практики, короткі повідомлення УДК 612.83:612.662.9:618.173-073.7/-076-085:615.2.1-092.9

DOI 10.11603/1811-2471.2020.v.i2.11334

\title{
МОНОСИНАПТИЧНІ ВІДПОВІДІ ВЕНТРАЛЬНИХ КОРІНЦІВ СПИННОГО МОЗКУ В УМОВАХ ЕКСПЕРИМЕНТАЛЬНОÏ ГІПОАНДРОГЕНЕМІЇ
}

\author{
๑О. Г. Родинський, С. С. Ткаченко, І. О. Маража \\ ДЗ «Дніпропетровська медична академія МОЗ України»
}

РЕзЮМЕ. Досліджень, присвячених змінам біоелектричної активності мотонейронів спинного мозку, що виникають у віддалені строки гіпоандрогенемії, майже немає. Ця проблема є маловивченою та актуальною.

Мета - вивчення біоелектричної активності моторного апарату спинного мозку шляхом аналізу викликаних моносинаптичних розрядів (МР) вентрального корінця (ВК) за умов експериментальної гіпоандрогенемії через 4 місяці від початку її моделювання.

Матеріал і методи. Дослідження виконане на щурах-самцях лінії Wistar віком 5-6 міс. та вагою 180-260 г, що були поділені на піддослідну ( $n=10)$ та контрольну ( $n=12)$ групи. Експериментальну модель було створено шляхом хірургічної кастрації. Відведення викликаної активності проводили від ізольованого вентрального корінця при стимуляції проксимальної ділянки іпсилатерального дорсального корінця сегмента $\mathrm{L}_{5}$ імпульсами тривалістю 0,3 мс та силою від 1 до 5 порогів. Аналізували поріг, хронаксію, латентний період, амплітуду та тривалість викликаних потенціалів, а також досліджували явище рефрактерності за допомогою нанесення парних стимулів з інтервалом від 1 до 1000 мс. Динаміку розповсюдження збудження на різнопорогові нейрони вивчали застосовуючи подразник зростаючої інтенсивності (від 1,1 до 2 П).

Результати. У тварин з орхектомією поріг збудження достовірно збільшувався на $(35,29 \pm 8,7) \%$, хронаксія зменшувалась на $(6,2 \pm 2,66)$ \%, тривалість латентного періоду зростала на $(4,59 \pm 0,88)$ \% відносно відповідних показників контрольної групи. Застосування подразнення зростаючої інтенсивності виявило більш швидке зростання амплітуди інтегральної відповіді у тварин з експериментальною гіпоандрогенемією на проміжку від 1,1 П до 1,6 П. При нанесенні парних стимулів відновлення амплітуди відповіді на тестуючий стимул мало більш повільний характер при інтервалах від 20 до 200 мс.

Висновки. У віддалених строках гіпоандрогенемії спостерігається відносне зниження порогу збудження середньо- та високопорогових мотонейронів на фоні загального зниження їх збудливості та збільшення тривалості латентного періоду. Також спостерігається зниження лабільності, обумовлене більш за все посиленням явищ гомосинаптичної депресії.

КлючОВІ СлОВА: андрогени, кастрація, мотонейрони, спинний мозок, біоелектрична активність.

Вступ. Існує велика кількість робіт, що описують вплив андрогенів на мотонейрони спинного мозку [1-4]. Зокрема, хвороба Кеннеді асоціюється з порушенням андрогенної чутливості через поліморфізм андрогенових рецепторів і характеризується нервово-м'язовими розладами та проксимальною м'язовою слабкістю через дегенерацію мотонейронів. Ця прогресуюча нейродегенеративна хвороба викликана генетичною експансією поліглутамінових рецепторів андрогенів [5-7]. $\epsilon$ інформація, що застосування антагоніста андрогенових рецепторів Флутаміду пришвидшує початок бокового аміотрофічного склерозу та розвиток рухової дисфункції у самців щурів SOD1G93A [8]. Але досліджень, присвячених змінам біоелектричної активності центральної ланки соматичної рефлекторної дуги, що виникають у віддалені строки гіпоандрогенемії (ЕГ), майже немає, ця проблема $\epsilon$ маловивченою та актуальною.

Метою дослідження було вивчення біоелектричної активності моторного апарату спинного мозку шляхом аналізу викликаних моносинаптичних розрядів (МР) вентрального корінця (ВК) за умов експериментальної гіпоандрогенемії через 4 місяці від початку її моделювання.
Матеріал і методи дослідження. Дослідження виконане на щурах-самцях лінії Wistar віком 5-6 міс. та вагою 180-260 г, що були поділені на піддослідну ( $n=10)$ та контрольну $(n=12)$ групи. Андрогенемію було модельовано шляхом двобічної орхектомії. Обидві групи тварин утримували в стандартних умовах віварію $\left(t^{\circ}(22 \pm 2){ }^{\circ} \mathrm{C}\right.$, світлий/ темний цикл - 12/12 год) на стандартній дієті протягом 120 діб, після чого тварини були задіяні у гострому експерименті. Для наркозу вводили тіопентал натрію в дозі 50 мг/кг маси. Після ламінектомії та дуротомії (під загальною анестезією) спинний мозок (CM) перетинали на рівні $\mathrm{Th}_{12}-\mathrm{L}_{1}$ та ізолювали дорсальні та вентральні корінці сегмента $L_{5}$. Через 3 години подразнювальні електроди розташовували на проксимальному відрізку дорсального корінця СМ, відведення проводили від проксимального відрізка вентрального корінця. Для подразнення використовували прямокутні імпульси силою від 1 до 2 порогів та тривалістю 0,3 мс. 3 метою аналізу динаміки розповсюдження збудження на різнопорогові нейрони застосовували подразники зростаючої інтенсивності (від 1,1 до 2 П). Модифікацію фаз рефрактерності вивчали методом нанесення парних стимулів (з міжстимульним 
Огляди літератури, оригінальні дослідження, погляд на проблему, випадок з практики, короткі повідомлення інтервалом від 1 до 1000 мс) [9]. Статистичну о6робку матеріалів дослідження проводили з використанням методів біометричного аналізу, реалізованих в ліцензійних пакетах EXCEL-2003® i STATISTICA 6.1 (StatSoft Inc., Serial No. AGAR909E415822FA). Вірогідність оцінювали за допомогою методів параметричної статистики (t критерій Стьюдента). Зміни показників вважали вірогідними при р<0,05. Всі експериментальні процедури були виконані відповідно до Європейської директиви Ради співтовариств від 24 листопада 1986 р. (86/609/ЕЕС).

Результати й обговорення. При дослідженні порогу виникнення МР ВК у тварин інтактної групи було встановлено, що за силою струму величина цього параметра становила $(0,0017 \pm 0,00009)$ мА (n=12). У тварин з орхектомією цей параметр збільшувався на $(35,29 \pm 8,7) \%(p<0,01, n=10)$ відносно

показника контрольної групи тварин, прийнятого за $100 \%$, що у абсолютних числах становило $(0,0023 \pm 0,0002) \mathrm{MA}$.

Хронаксія МР ВК у тварин контрольної групи становила $(97,33 \pm 2,92)$ мкс $(n=12)$, а у тварин з експериментальною гіпоандрогенемією цей показник зменшувався на $(6,2 \pm 2,66) \%(p<0,05, n=10)$, що в абсолютних значеннях становило $(91,30 \pm 2,43)$ мкс.

Аналіз характеристик МР BK показав, що за умов експериментальної гіпоандрогенемії достовірних, але невеликих змін зазнавав лише латентний період: його значення, порівняно з аналогічним показником контрольної групи, достовірно зростало на $(4,59 \pm 0,88) \%(p<0,01)$. Загальна тривалість МР ВК та амплітуда викликаної відповіді лише демонстрували тенденцію до зменшення, але достовірними ці зміни не були $(p>0,05)$ (табл. 1).

Таблиця 1. Характеристики моносинаптичних розрядів вентрального корінця спинного мозку білих щурів

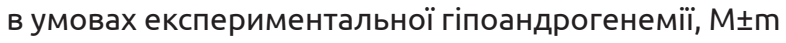

\begin{tabular}{|l|c|c|}
\hline \multicolumn{1}{|c|}{ Параметри } & Контроль $(\mathrm{n}=12)$ & Тварини з ЕГ ( $\mathrm{n=10)}$ \\
\hline Латентний період, мс & $1,09 \pm 0,01$ & $1,14 \pm 0,01$ ** \\
\hline Загальна тривалість, мс & $1,74 \pm 0,05$ & $1,71 \pm 0,04$ \\
\hline Амплітуда, мВ & $2,70 \pm 0,22$ & $2,61 \pm 0,13$ \\
\hline
\end{tabular}

Примітка: ** - рівень вірогідності p<0,01.

Застосування подразнення зростаючої інтенсивності виявило більш швидке зростання амплітуди інтегральної відповіді у тварин з експериментальною гіпоандрогенемією на проміжку від 1,1 П до 1,6 П, особливо до 1,3 П включно. При інтенсив- ності подразнення 1,1 П різниця становила $(117,8 \pm$ $18,72) \%, 1,2$ П $(72,2 \pm 10,97) \%, 1,3 \sqcap-(46,6 \pm 6,52) \%$ (n=10, p<0,001). При подальшому застосуванні сили стимуляції понад 1,6 П достовірних відмінностей між групами щурів виявлено не було (рис. 1).

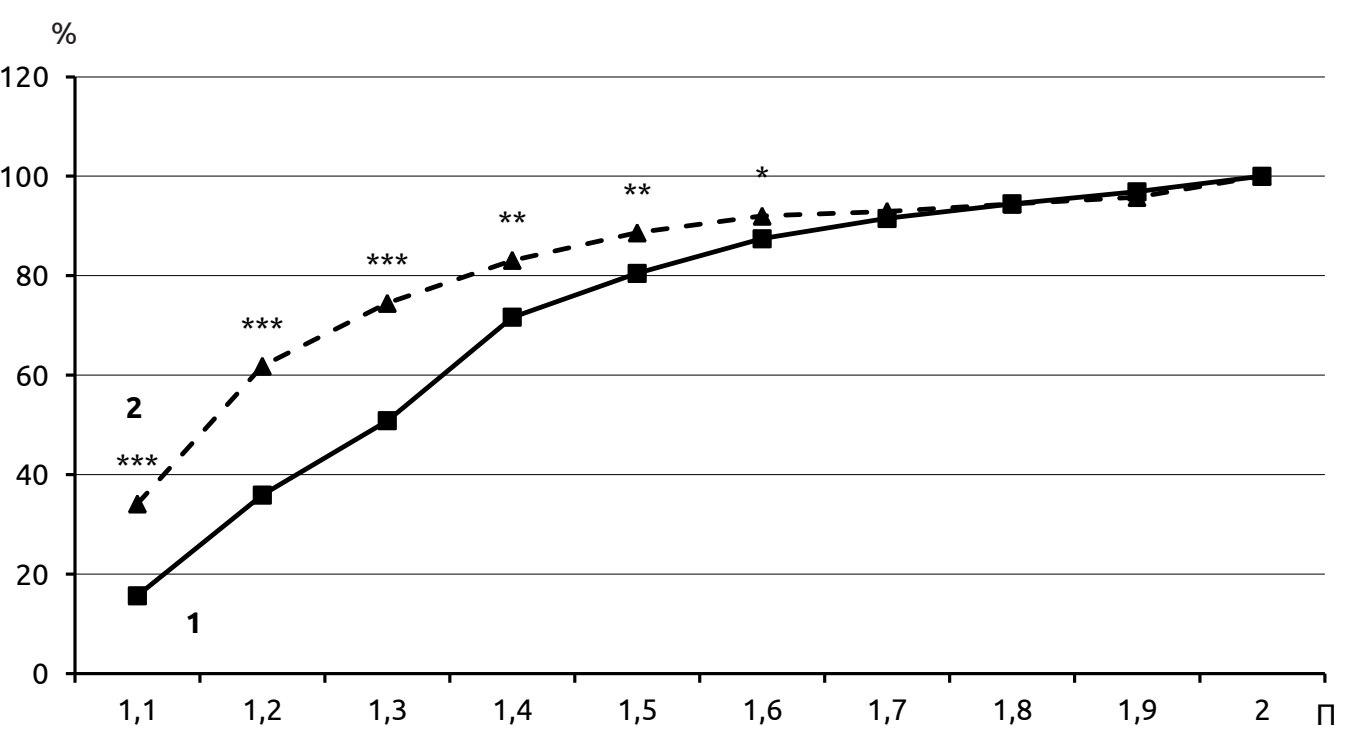

Рис. 1. Динаміка зміни амплітуди моносинаптичних розрядів вентрального корінця спинного мозку у відповідь на стимуляцію зростаючої інтенсивності: 1 - контрольні тварини; 2 - тварини з ЕГ.

При аналізі динаміки відновлення амплітуди другого ПД при нанесенні парних подразнень $з$ різними часовими інтервалами виявлено, що у контрольних тварин при інтервалі між стимулами 3 - 100 мс спостерігалося пригнічення амплітуди відповіді на тестуючий стимул з максимумом при 
Огляди літератури, оригінальні дослідження, погляд на проблему, випадок з практики, короткі повідомлення міжстимульному інтервалі 10 мс $((12,31 \pm 1,73) \%$ амплітуди відповіді на кондиціонуючий стимул) 3 наступним його поступовим відновленням. У тварин з експериментальної групи динамічна крива мала такий самий профіль, проте пригнічення розпочиналось при інтервалі 3 мс та сягало макси-

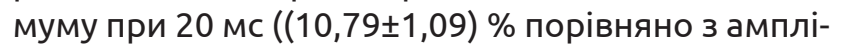
тудою першого ПД). Крім того, пригнічення на проміжку від 3 до 7 мс мало менш виражений ха-

рактер, а відновлення амплітуди відповіді на тестуючий стимул було більш повільним. Так, при інтервалі між подразненнями 30 мс амплітуда другого ПД у тварин контрольної групи складала $(35,83 \pm 2,56) \%(n=10)$ від амплітуди першого, тоді як у кастрованих тварин цей показник досяг лише $(15,91 \pm 1,29) \%(n=10, p<0,001)$. Починаючи зі 100 мс і до 1000 мс включно обидва графіки майже збігалися (рис. 2).

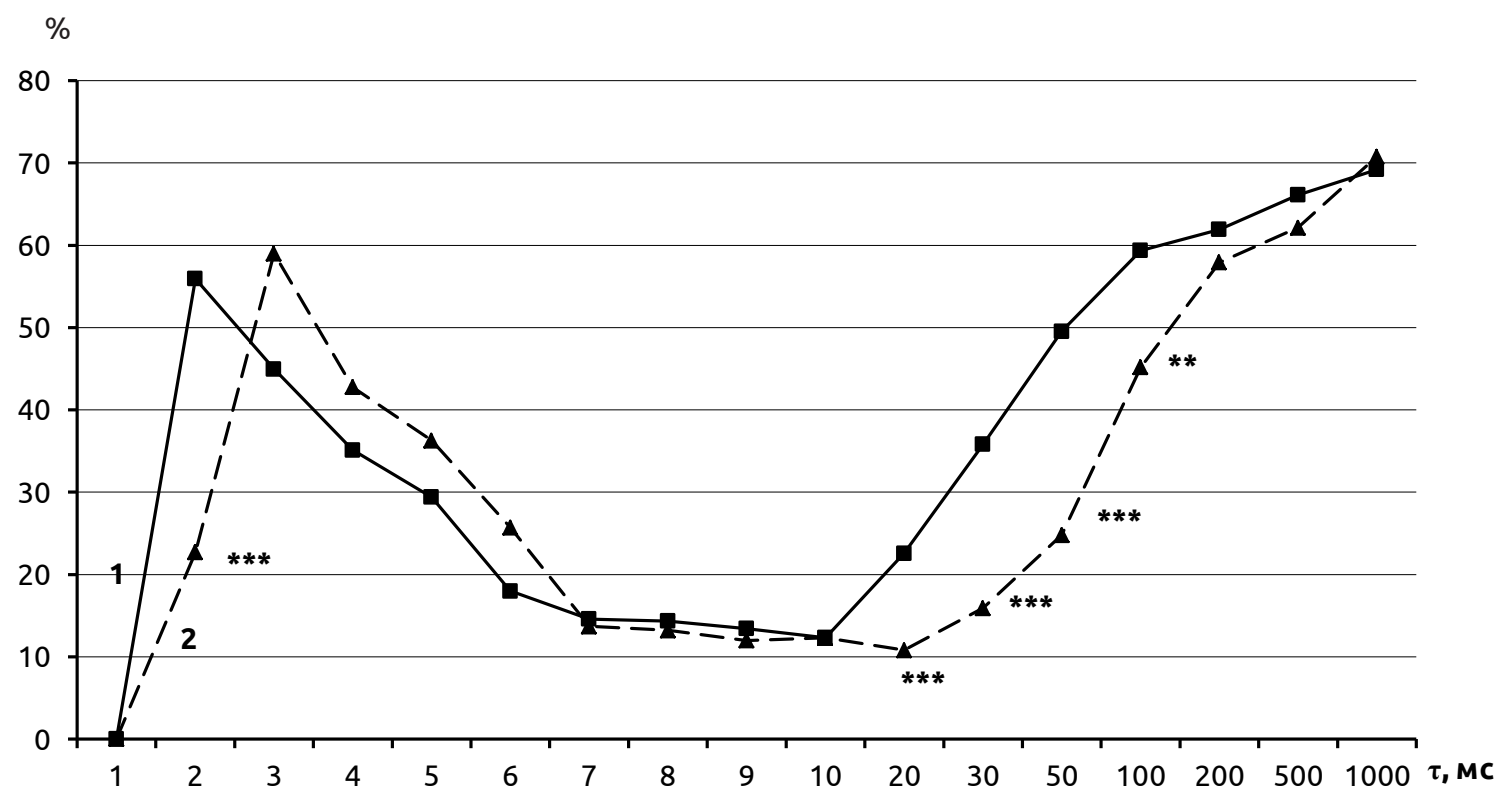

Рис. 2. Характер гальмування моносинаптичного вентрального корінця спинного мозку у відповідь на тестуючий стимул: 1 - контрольні тварини; 2 - тварини з ЕГ.

Рівень вірогідності: ** - p<0,01; *** - p<0,001 за відношенням до відповідних значень контрольної групи.

Відомо, що зниження впливу андрогенів на мотонейрони призводить до їх дегенерації [10]. Андрогени забезпечують нейропротекцію нейронів ЦНС від викликаного нестачею ростових факторів апоптозу [11]. Нейропротекція може бути опосередкована послабленням окисного стресу $[4,12]$. Виявлено зворотну кореляцію між зниженням рівня тестостерону і збільшенням активності NADPH-діафорази, надлишок якого веде до підвищення синтезу супероксид-аніону, що стимулює окиснювальний стрес, i, в свою чергу, може викликати апоптоз нейронів [13].

Відомо, що клітини-сателіти скелетних м'язів продукують BDNF, що діє як ретроградно транспортований трофічний фактор, рівень якого, разом з його рецептором TrkB у мотонейронах, контролюється андрогенами [3]. Впливаючи на розмір соми, морфологію дендритів і регенерацію аксона [2] тестостерон зменшує ступінь пошкодження спинного мозку in vitro [14]. Порушення нормального регенеративного процесу мотонейронного пулу через нестачу андрогенів з їх нейропротекторними власти- востями може призводити до морфологічних змін, що може обумовлювати порушення функціонування мотонейронів. Насамперед це може призвести до зниження їх збудливості та біоелектричної активності, що проявлялося як підвищення порогу збудження, збільшення тривалості латентного періоду та тенденція до зниження середнього значення амплітуди викликаної відповіді (див. табл. 1). Останнє, як і тенденцію до зниження тривалості інтегрального ПД, можна пояснити частковою загибеллю мотонейронів через зниження модулюючого впливу андрогенів на процеси апоптозу нервових клітин. Зменшення хронаксії відбувалось у відповідності з кривою залежності «сила - час».

Андрогени, взаємодіючи з мембранними рецепторами [10], можуть призводити до зміни рівня внутрішньоклітинного [Ca $\left.{ }^{2+}\right]$ i [15]. Іонний канал транзієнтного рецепторного потенціалу (TRP) сімейства TRPM8, що має відносно високу селективність відносно Са ${ }^{2+}$ i низьку селективність серед одновалентних катіонів, $є$ основним компонентом швидкої дії тестостерону [16]. 
Огляди літератури, оригінальні дослідження, погляд на проблему, випадок з практики, короткі повідомлення

Гіпоандрогенемія може призводити до зниження концентрації внутрішньоклітинного кальцію, що тягне за собою збільшення потенціалу спокою, а отже й зниження збудливості сенсорних волокон. Крім того, зниження рівня цитоплазматичного кальцію у пресинаптичних закінченнях збільшує тривалість латентного періоду вивільнення медіатора, а отже й інерційність синаптичної передачі. Це може бути однією із причин достовірного подовження латентного періоду, викликаного МР ВК (див. табл. 1).

Андрогени мають специфічний сайт зв'язування на нейротрансмітерних рецепторах, зокрема рецепторі гамма-аміномасляної кислоти A (GABAA). Зв'язування з GABAA рецепторами модулює активність нейронів за допомогою змін постсинаптичного гальмування, ймовірно, через вплив на хлорний трансмембранний струм [15]. Існують дані, що деякі стероїди є сильнодіючими алостеричними модуляторами рецептора ГАМК у ЦНС [17].

Отже, дефіцит андрогенів може викликати протилежний ефект через зниження гальмівної дії стероїдів на хлорний ГАМК-залежний канал, обумовлюючи інтенсифікацію пресинаптичного гальмування. Останнє, в свою чергу, може пояснити підвищення порогу збудження мотонейронів при подразненні волокон дорсального корінця.

Застосування андрогенів у кастрованих тварин приводило до значного і тривалого збільшення BDNF експресії в мотонейронах і зменшувало кількість синаптичних відходів після пошкодження нерва, а також прискорення регенерації аксона. Було виявлено аналогічне скорочення втрат синапсів після лікування тестостероном у самців щурів, схильних до хронічного стресу. [18] У свою чергу, кастрація зменшує як розмір, так і кількість синаптичних контактів на мотонейронах [3].

Крім того, андрогени контролюють рівні білка BDNF у дендритах мотонейрона та в їх глутаматергічних аферентах, багато з яких експресують TrkB, що вказує на те, що опосередкована андрогенами сигналізація BDNF може підтримувати збуджуючі входи в мотонейрони [3].

Існують дослідження, згідно з якими андрогени істотно сприяють реорганізації синаптичних входів спінальних мотонейронів. Так, наприклад, середнє значення загальної площі синаптичних контактів на мембрані соми і проксимальних ділянок дендритів мотонейронів SNB через 4 тижні після кастрації дорослих самців щурів знижувалось до 30 \%, що запобігалось застосуванням замісної гормональної терапії [1].

Оскільки, як відомо, викликана відповідь мотонейронів обумовлена просторовою сумацією подразнювальних та гальмівних стимулів на його ней- ролемі, зменшення площі синаптичних контактів на мембрані соми і проксимальних ділянок дендритів мотонейронів може пояснити збільшення порогу їх збудження та тривалості латентного періоду, а також тенденцію до зниження середнього значення амплітуди викликаного ПД, що було зафіксовано у тварин піддослідної групи (див. табл. 1).

Нестача андрогенів може призводити до порушення репаративних процесів у мієліновій оболонці нервових волокон, а при тривало існуючому гострому дефіциті, як то після хірургічної кастрації, спричинити демієлінізацію [19]. Пошкодження мієлінової оболонки призводить до генералізації збудження через ефаптичний ефект та залучення, поряд із низькопороговими, високопорогових аферентних входів мотонейронів спинного мозку, що спостерігалося нами при нанесенні подразнювальних стимулів зростаючої інтенсивності (див. рис. 1).

Андрогени впливають на обіг цитоскелетної матриці, відповідальної за структуру аксона [20]. У зв'язку з цим відомо, що фосфорилювання як С-кінцевих ділянок, так і головного домену нейрофіламентів, сприяє регулюванню взаємодій нейрофіламентів один з одним, нейрофіламентів з мікротрубочками і взаємодій між мікротрубочками та моторними білками. Останні, як відомо, відповідальні за аксональний транспорт [20].

Нестача андрогенів може викликати порушення аксонального транспорту, а, отже, й зниження лабільності через посилення явищ гомосинаптичної депресії, обумовленої, в свою чергу, виснаженням запасів нейротрансмітерів у пресинаптичних закінченнях аферентних входів мотонейронів та порушенням процесу їх відновлення через аксональний транспорт. Зазначене вище може пояснити більш тривалу депресію викликаної відповіді на тестуючий стимул у групі піддослідних тварин при застосуванні парних подразнювальних імпульсів (рис. 2).

Висновки. У віддалених строках гіпоандрогенемії спостерігаються значні зміни в функціонуванні центральної ланки сегментарної моносинаптичної рефлекторної дуги СМ у вигляді відносного зниження порогу збудження середньо- та високопорогових мотонейронів на фоні загального зниження їх збудливості та збільшення тривалості латентного періоду. Також спостерігається зниження лабільності, обумовлене, найімовірніше, посиленням явищ гомосинаптичної депресії. Проте можливо, що зниження лабільності частково обумовлене посиленням пресинаптичного та постсинаптичного гальмування зі сторони інтернейронного пулу, тому це питання потребує подальшого вивчення. 


\section{ЛІТЕРАТУРА}

1. Matsumoto A. Androgen regulates synaptic input to motoneurons of the adult rat spinal cord / A. Matsumoto, P. E. Micevych, A. P. Arnold // J. Neuroscience. - 1988. Vol. 8, No. 11. - P. 4168-4176.

2. Verhovshek T. BDNF and androgen interactions in spinal neuromuscular systems / T. Verhovshek, L. M. Rudolph, D.R.Sengelaub//Neuroscience.-2013.-No.239.-P.103-114.

3. Fargo K. N. Androgen regulation of axon growth and neurite extension in motoneurons / K. N. Fargo, M. Galbiati, E. M. Foecking // Hormones and Behavior. - 2008. Vol. 53, No. 5. - P. 716-728.

4. Fargo K. N. Neuroprotective actions of androgens on motoneurons / K. N. Fargo, E. M. Foecking, K. J. Jones // Frontiers in Neuroendocrinology. - 2009. - Vol. 30, No. 2. P. 130-141.

5. Finsterer J. Central nervous system abnormalities in spinal and bulbar muscular atrophy (Kennedy's disease) / J. Finsterer, F. A. Scorza // Clinical Neurology and Neurosurgery. - 2019. - No. 184. - P. 105426. DOI: 10.1016/j.clineuro.2019.105426.

6. Clinical manifestations and AR gene mutations in Kennedy's disease / X. Liu, M. Zhu, X. Li, J. Tang // Functional \& Integrative Genomics. - 2019. - Vol. 19, No. 3. - P. 533539. - ISSN 1438-7948. DOI: 10.1007/s10142-018-0651-7.

7. Selective modulation of the androgen receptor AF2 domain rescues degeneration in spinal bulbar muscular atrophy / N. M. Badders, A. Korff, H. C. Miranda [et al.] // Nature Medicine. - 2018. - Vol. 24, No. 4. - P. 427-437.

8. Androgen receptor antagonism accelerates disease onset in the SOD1G93A mouse model of amyotrophic lateral sclerosis / V. M. McLeod, C. L. Lau, M. D. F. Chiam [et al.] // British Journal of Pharmacology. 2019. - Vol. 176, No. 13. - P. 2111-2130.

9. Родинський О. Г. Моносинаптичні відповіді вентральних корінців спинного мозку в умовах експериментальної менопаузи / О. Г. Родинський, С. С. Ткаченко, Л. В. Гузь // Клінічна та експериментальна патологія. - 2015. - T. XIV, № 4 (54). - С. 128-132.

10. Narayanan R. Selective androgen receptor modulators in preclinical and clinical development / R. Narayanan, M. L. Mohler, C. E. Bohl // Nuclear Receptor Signaling
Atlas. -2008. - No. 6. - P. 1-26.

11. Hammond J. Testosterone-mediated neuroprotection through the androgen receptor in human primary neurons / J. Hammond, Q. Le, C. Goodyer // Journal of Neurochemistry. - 2001. - No. 77. - P. 1319-1326.

12. Pike C. J. Protective actions of sex steroid hormones in Alzheimer's disease / C. J. Pike, J. C. Carroll, E. R. Rosario // Frontiers in Neuroendocrinology. - 2009. Vol. 30, No. 2. - P. 239-258.

13. Дмитриева О. А. Влияние стресс-индуцированного снижения уровня тестостерона на гистохимические изменения половых органов крыс / О. А. Дмитриева, Б. В. Шерстюк // Pacific Medical Journal. - 2007. № 3. - P. 55-57.

14. Biatek M. Neuroprotective role of testosterone in the nervous system / M. Biatek, P. Zaremba, K. K. Borowicz // Polish Journal of Pharmacology. - 2004. - No. 56. P. 509-518.

15. Foradori C. D. Non-genomic Actions of Androgens / C. D. Foradori, M. J. Weiser, R. J. Handa // Frontiers in Neuroendocrinology. - 2008. - Vol. 29, No. 2. - P. 169-181.

16. The TRPM8 protein is a testosterone receptor / S. Asuthkar, L. Demirkhanyan, X. Sun [et al.] // The Journal of Biological Chemistry. - 2015. - Vol. 290, No. 5. P. 2670-2688.

17. Neurosteroids and GABAA receptor function / J. J. Lambert, D. Belelli, C. Hill-Venning, J. A. Peters//Trends in Pharmacological Sciences. - 1995. - Vol. 16, No. 9. P. 295-303.

18. Liu C. The effects of exercise on synaptic stripping require androgen receptor signaling / C. Liu, P. J. Ward, A. W. English // PLoS ONE. - 2014. - Vol. 9, No. 6. P. e98633. DOI: 10.1371/journal.pone.0098633.

19. Hussain R. The neural androgen receptor: a therapeutic target for myelin repair in chronic demyelination / R. Hussain, A. M. Ghoumari, B. Bielecki // Brain a Journal of Neurology. - 2013. - No. 136. - P. 132-146.

20. Pesaresi M. Axon diameter and axonal transport: In vivo and in vitro effects of androgens / M. Pesaresi, R. SoonShiong, L. French. // Neuroimage. - 2015. - No. 115. P. 191-201.

\section{REFERENCES}

1. Matsumoto, A., Micevych, P.E., \& Arnold, A.P. (1988). Androgen regulates synaptic input to motoneurons of the adult rat spinal cord. Neuroscience, 8(11), 4168-4176. ISSN: 0270-6474

2. Verhovshek, T., Rudolph, L.M., \& Sengelaub, D.R. (2013). BDNF and androgen interactions in spinal neuromuscular systems. Neuroscience, 239, 103-114. ISSN: 02706474

3. Fargo, K.N., Galbiati, M., Foecking, \& E.M. (2008). Androgen regulation of axon growth and neurite extension in motoneurons. Hormones and Behavior, 53(5), 716-728. ISSN: 0018-506X

4. Fargo, K.N., Foecking, E.M., \& Jones, K.J. (2009). Neuroprotective actions of androgens on motoneurons.

Frontiers in Neuroendocrinology, 30 (2), 130-141. ISSN: 0091-3022

5. Finsterer, J., \& Scorza, F.A. (2019). Central nervous system abnormalities in spinal and bulbar muscular atrophy (Kennedy's disease). Clinical Neurology and Neurosurgery, 184, 105426. DOI: 10.1016/j.clineuro.2019.105426. ISSN: 0303-8467

6. Liu, X., Zhu, M., Li, X., Tang, J. (2019). Clinical manifestations and AR gene mutations in Kennedy's disease. Functional \& Integrative Genomics, 19(3), 533-539. DOI: $10.1007 / \mathrm{s} 10142-018-0651-7$. ISSN: 1438-7948

7. Badders, N.M., Korff, A., Miranda, H.C., Vuppala, P.K., Smith, R.B., et al. (2018). Selective modulation of the androgen receptor AF2 domain rescues degeneration 
Огляди літератури, оригінальні дослідження, погляд на проблему, випадок з практики, короткі повідомлення in spinal bulbar muscular atrophy. Nature Medicine, 24(4), 427-437. doi: 10.1038/nm.4500. ISSN: 1078-8956

8. McLeod, V.M., Lau, C.L., Chiam, M.D.F., Rupasinghe, T.W., Roessner, U., et all. (2019). Androgen receptor antagonism accelerates disease onset in the SOD1G93A mouse model of amyotrophic lateral sclerosis. British Journal of Pharmacology, 176(13), 2111-2130. DOI: 10.1111/ bph.14657. ISSN: 0007-1188

9. Rodynskiy, O.G., Tkachenko, S.S., \& Huz, L.V. (2015). Monosynaptychni vidpovidi ventralnykh korintsiv spynnoho mozku v umovah eksperymentalnoi menopauzy [Monosynaptic responses of the ventral roots of the spinal cord in experimental menopause]. Klinichna ta eksperymentalna patolohiia - Clinical and Experimental Pathology, 4 (54), 128-132. ISSN 1727-4338

10. Narayanan, R., Mohler, M.L., \& Bohl, C.E. (2008). Selective androgen receptor modulators in preclinical and clinical development. Nuclear Receptor Signaling Atlas, 6, 1-26. DOI: 10.1621/nrs.06010. ISSN: 15507629

11. Hammond, J., Le, Q., \& Goodyer, C. (2001). Testosterone-mediated neuroprotection through the androgen receptor in human primary neurons. Journal of Neurochemistry,77,1319-1326.DOI:10.1046/j.1471-4159.2001.00345. ISSN: 0022-3042

12. Pike, C.J., Carroll, J.C., \& Rosario, E.R. (2009). Protective actions of sex steroid hormones in Alzheimer's disease. Frontiers in Neuroendocrinology, 30 (2), 239-258. DOI: 10.1016/j.yfrne.2009.04.015. ISSN: 0091-3022

13. Dmitriyeva, O.A., \& Sherstyuk, B.V. (2007). Vliyaniye stress-indutsirovannogo snizheniya urovnya testosterona na gistokhimicheskiye izmeneniya polovykh organov krys [The effect of stress-induced decrease in testosterone le-

vels on histochemical changes in genital organs of rats]. $\mathrm{Pa}$ cific Medical Journal, 3, 55-57. ISSN: 0022-3042

14. Biatek, M., Zaremba, P., Borowicz, K.K. (2004). Neuroprotective role of testosterone in the nervous system. Polish Journal of Pharmacology, 56 (5), 509-518. ISSN 1230-6002.

15. Foradori, C.D., Weiser, M.J., \& Handa, R.J. (2008). Non-genomic actions of androgens. Frontiers in Neuroendocrinology, 29 (2), 169-181. DOI: 10.1016/j.yfrne.2007.10.005. ISSN: 0091-3022.

16. Asuthkar, S., Demirkhanyan, L., Sun, X., Elustondo, P.A., Krishnan, V., et al. (2015). The TRPM8 protein is a testosterone receptor. The Journal of Biological Chemistry, 290 (5), 2670-88. DOI: 10.1074/jbc.M114.610873. ISSN: 0021-9258.

17. Lambert, J.J., Belelli, D., Hill-Venning, C., \& Peters, J.A. (1995). Neurosteroids and GABAA receptor function. Trends in Pharmacological Sciences, 16 (9), 295-303. DOI: $10.1016 /$ s0165-6147(00)89058-6. ISSN: 0165-6147.

18. Liu, C., Ward, P.J., \& English, A.W. (2014). The effects of exercise on synaptic stripping require androgen receptor signaling. PLOS ONE, 9 (6), e98633. DOI: 10.1371/ journal.pone.0098633. ISSN: 1932-6203

19. Hussain, R., Ghoumari, A.M., \& Bielecki, B. (2013). The neural androgen receptor: a therapeutic target for myelin repair in chronic demyelination. Brain a Journal of Neurology, 136, 132-146. DOI: 10.1093/brain/aws284. ISSN: 0006-8950

20. Pesaresi, M., Soon-Shiong, R., \& French, L. (2015). Axon diameter and axonal transport: In vivo and in vitro effects of androgens. Neuroimage, 115, 191-201. DOI: 10.1016/j.neuroimage.2015.04.048. ISSN: 1053-8119

\title{
МОНОСИНАПТИЧЕСКИЕ ОТВЕТЫ ВЕНТРАЛЬНЫХ КОРЕШКОВ СПИННОГО МОЗГА В УСЛОВИЯХ ЭКСПЕРИМЕНТАЛЬНОЙ ГИПОАНДРОГЕНЕМИИ
}

\author{
๑А. Г. Родинский, С. С. Ткаченко, И. А. Маража \\ ГУ «Днепропетровская медицинская академия МОЗ Украины»
}

РЕЗЮМЕ. Исследований, посвященных изменениям биоэлектрической активности мотонейронов спинного мозга, возникающих в отдаленные сроки гипоандрогенемии, почти нет. Данная проблема является малоизученной и актуальной.

Цель - изучение биоэлектрической активности моторного аппарата спинного мозга путем анализа вызванных моносинаптических разрядов вентрального корешка в условиях экспериментальной гипоандрогенемии через 4 месяца после начала ее моделирования.

Материал и методы. Исследование выполнено на крысах-самцах линии Wistar в возрасте 5-6 мес. и весом 180-260 г, которые были поделены на подопытную $(n=10)$ и контрольную $(n=12)$ группы. Экспериментальная модель была создана путем хирургической кастрации. Отвод вызванной активности проводили от изолированного вентрального корешка при стимуляции проксимального участка ипсилатерального дорсального корешка сегмента $\mathrm{L}_{5}$ импульсами длительностью 0,3 мс и силой от 1 до 5 порогов. Анализировали порог, хронаксию, латентный период, амплитуду и длительность вызванных потенциалов, а также исследовали явление рефрактерности с помощью нанесения парных стимулов с интервалом от 1 до 1000 мс. Динамику распространения возбуждения на разнопороговые нейроны изучали применяя стимул возрастающей интенсивности (от 1,1 до 2 П).

Результаты. У животных с орхэктомией порог возбуждения достоверно увеличивался на $(35,29 \pm 8,7) \%, x р о-$ наксия уменьшалась на $(6,2 \pm 2,66) \%$, продолжительность латентного периода увеличивалась на $(4,59 \pm 0,88) \%$ относительно соответствующих показателей контрольной группы. Применение стимулов возрастающей интенсивности выявило более быстрый рост амплитуды интегрального ответа у животных с экспериментальной гипоандрогенемией на промежутке от 1,1 П до 1,6 П. При нанесении парных стимулов восстановление амплитуды ответа на тестирующий стимул имело более медленный характер при интервалах от 20 до 200 мс. 
Огляди літератури, оригінальні дослідження, погляд на проблему, випадок з практики, короткі повідомлення

Выводы. В отдаленные сроки гипоандрогенемии наблюдается относительное снижение порога возбуждения средне- и высокопороговых мотонейронов на фоне общего снижения их возбудимости, увеличения латентности и снижения лабильности, что обусловлено, скорее всего, усилением явлений гомосинаптической депрессии.

КЛЮчЕВЫЕ СЛОВА: андрогены, кастрация, мотонейроны, спинной мозг, биоэлектрическая активность.

\title{
MONOSYNAPTIC RESPONSES OF THE VENTRAL ROOTS OF THE SPINAL CORD UNDER EXPERIMENTAL HYPOANDROGENEMIA
}

\author{
@A. G. Rodinsky, S. S. Tkachenko, I. O. Marazha \\ Dnipropetrovsk Medical Academy
}

SUMMARY. There are almost no studies on changes in the bioelectrical activity of spinal cord motor neurons that occur in the long-term period of hypoandrogenemia. This problem is poorly understood and relevant.

The aim - to study of the bioelectrical activity of the motor apparatus of the spinal cord by analyzing induced monosynaptic discharges of the ventral root under experimental hypoandrogenemia 4 months after the start of its modeling

Material and Methods. The study was performed on male Wistar rats aged 5-6 months and weighing 180-260 g, which were divided into experimental $(n=10)$ and control $(n=12)$ groups. An experimental model was created by surgical castration. Evoked activity was withdrawn from an isolated ventral root during stimulation of the proximal portion of the ipsilateral dorsal root of the $L_{5}$ segment with pulses of 0.3 ms duration and strength from 1 to 5 thresholds. The threshold, chronaxy, latency, amplitude and duration of evoked potentials were analyzed, and the phenomenon of refractoriness was studied by applying paired stimuli with an interval of 1 to $1000 \mathrm{~ms}$. The dynamics of the propagation of excitation on multithreshold neurons was studied using a stimulus of increasing intensity (from 1.1 to 2 P).

Results. In animals with orchiectomy, the threshold of excitation increased by $(35.29 \pm 8.7) \%$, chronaxy decreased by $(6.2 \pm 2.66) \%$, the duration of the latent period increased by $(4.59 \pm 0.88) \%$ relative to the corresponding indices of the control group. The use of increasing intensity stimuli revealed a faster increase in the response amplitude in animals with experimental hypoandrogenemia in the interval from 1.1 to 1.6 threshold. When applying paired stimuli, the restoration of the response amplitude to the test stimulus was slower at intervals of 20 to $200 \mathrm{~ms}$.

Conclusions. In the long-term periods of hypoandrogenemia, a relative decrease in the excitation threshold of medium and high threshold motor neurons is observed against the background of a general decrease in their excitability, an increase in latency and a decrease in lability, which is most likely due to an increase in the phenomena of homosynaptic depression.

KEY WORDS: androgens; castration; motor neurons; spinal cord; bioelectric activity. 